\title{
Gibberellic Acid Can Improve Seed Germination and Ornamental Quality of Selected Cyclamen Species Grown Under Short and Long Days
}

\author{
Mihaiela Cornea-Cipcigan ${ }^{1}{ }^{1}$, Doru Pamfil ${ }^{1}$, Cristian Radu Sisea ${ }^{1,2, *}$ and Rodica Mărgăoan ${ }^{2, *}$ \\ 1 Department of Horticulture and Landscaping, Faculty of Horticulture, University of Agricultural Sciences \\ and Veterinary Medicine Cluj-Napoca, 400372 Cluj-Napoca, Romania; \\ mihaiela.cornea@usamvcluj.ro (M.C.-C.); dpamfil@usamvcluj.ro (D.P.) \\ 2 Department of Microbiology and Biotechnologies, Advanced Horticultural Research Institute of \\ Transylvania, University of Agricultural Sciences and Veterinary Medicine Cluj-Napoca, \\ 400372 Cluj-Napoca, Romania \\ * Correspondence: cristian.sisea@usamvcluj.ro (C.R.S.); rodica.margaoan@usamvcluj.ro (R.M.)
}

Received: 13 February 2020; Accepted: 1 April 2020; Published: 3 April 2020

\begin{abstract}
Cyclamen species (swinebread spp.) are perennial herbaceous plants which belong to the Primulaceae family, widely used as medicinal or ornamental plants. Currently, gibberellic acid $\left(\mathrm{GA}_{3}\right)$, an environmentally friendly bioregulator is widely used to enhance the productivity and phenotypic characteristics of multiple ornamental crops. A dual experiment was conducted to evaluate the influence of gibberellic acid (50,100 or $150 \mathrm{mg} / \mathrm{L}$ ), on germination earliness of seeds, along with growth and ornamental quality of selected Cyclamen species. Additionally, a greenhouse experiment with long and short sunlight photoperiod was conducted to evaluate its importance in the development of Cyclamen plants. Our results indicated that under short sunlight exposure, seeds germinated earlier than those kept in long sunlight photoperiod. Plants treated with foliar applications of $\mathrm{GA}_{3}$ exhibited higher plant height, leaf area, number of leaves, root length and tuber development. Significant differences were found in germination percentage (GP), mean germination time (MGT) and seedling vigor index (SVI), within different $\mathrm{GA}_{3}$ supplementation and greenhouse sunlight intensity (short and long days). In conclusion, our study suggests that seedling vigor and ornamental quality can be increased by $\mathrm{GA}_{3}$ application, an economic strategy for enhancing germination and growth of selected Cyclamen species.
\end{abstract}

Keywords: Cyclamen species; germination parameters; gibberellic acid; photoperiod

\section{Introduction}

Cyclamen species (sowbread or swinebread spp.) are a class/group of popular herbaceous ornamental and medicinal plants distributed in and near the Mediterranean region [1]. Cultivation of Cyclamen species in regions such as northern Europe, North America, Japan, Australia and New Zealand underscores their remarkable ability and plasticity to adapt to new ecological environments. However, environmental degradation, displacement and habitat modifications along with tuber over-exploitation have exerted pressure on the native populations of these valuable ornamental species. Therefore, measures of protection were taken by including them in various conservation organizations. Cyclamen coum (eastern sowbread), Cyclamen hederifolium 'Alba' (ivy-leaved cyclamen or sowbread) and Cyclamen purpurascens (Alpine, European or purple cyclamen) are included in the IUCN (International Union for Conservation of Nature) Red List of Threatened Species [2]. Although C. hederifolium 'Alba' is included in CITES Appendix II, artificial propagation of new cultivars is allowed, being also listed as endangered in Switzerland [3]. C. purpurascens is considered to be endangered due to the collection 
of wild plants for medicinal purposes in Croatia [4]. Permanent loss of habitats resulting from the elimination and degradation of forests is probably a consequence that will lead to shrinking and extirpation of local populations.

Gibberellins (GA) are essential plant regulators for multiple plant development processes, including seed germination, stem elongation, leaf extension, pollen maturation, and flowering induction. Therefore, mutant plants that are deficient in GA have a dwarf phenotype and late flowering; treating these plants with GA restores normal growth. Gibberellic acid $\left(\mathrm{GA}_{3}\right)$ is a natural plant regulator with multiple applications in agriculture and horticulture industry due to its positive impact on plant growth and development. Its positive effects have been demonstrated in multiple crops and ornamental plants by exhibiting enhanced seed germination $[5,6]$, shortening the juvenile phase, leaf expansion and development, stem elongation [7,8], early flowering [9-13] and fruit development; their role in the promotion of flowering in plants was reported in several studies, including Arabidopsis thaliana (thale cress) [14], Brunonia australis R.Br. (blue pincushion or native cornflower) [15], Henckelia humboldtianus (Humboldt's Stone Flower) [16], and Iris nigricans Dinsm. (black iris) [17]. Nowadays an increasing interest in patterned foliages and long vase life of Cyclamen cut-flowers urged researchers to develop new protocols to fulfill the market requirements. Foliar applications of $\mathrm{GA}_{3}$ enhanced flower stem length in soil grown cut-flowers [18] and delayed leaf yellowing [19].

It is well known that day length, along with temperature and water supply, is one of the most important traits influencing growth and development of Cyclamen. Previous studies have confirmed that GAs contents significantly increased in the long-short day plant Bryophyllum daigremontianum (devil's backbone), when transferred from under long-day to short-day condition [20,21]. Huang [22] showed that flowering was induced in Kalanchoe pinnata (Goethe plant) and K. poincarei (alligator plant) plants when $5 \mathrm{mg} / \mathrm{L} \mathrm{GA}_{3}$ was applied on them. Therefore, exogenous GAs appears to promote the transition from vegetative growth to reproductive growth [14]. Light intensity is considered to be a stress to multiple plants, especially to Cyclamen, but also an important aspect with regards to plant growth and development. As described by the Cyclamen Society, sunlight below $100 \mu \mathrm{mol} \mathrm{m}{ }^{2} \mathrm{~s}^{-1}$ causes slow growth and poor quality in ordinary mini cyclamen, requiring supplemental lighting [23]. These conditions usually occur in greenhouses during winter (November to February) and summer rainy season. However, few studies have been conducted to trace the origin of high elongation rate under such conditions [8].

Taking into account the medicinal importance of Cyclamen, the aim of the study was to investigate the response of multiple Cyclamen species to different concentrations of $\mathrm{GA}_{3}$ under short and long day exposure. These methods were studied as a potential way to shorten the germination and propagation period of these Cyclamen species. Therefore, the main objective of this study was to determine (1) the effects of $\mathrm{GA}_{3}$ application on seed germination and plant development, and (2) the optimal $\mathrm{GA}_{3}$ dosage applied to Cyclamen accessions as affected by different sunlight intensities.

\section{Materials and Methods}

\subsection{Plant Materials}

A pot experiment was conducted between 2018-2019 (June to May) at the Advanced Horticultural Research Institute of Transylvania (AHRIT), University of Agricultural Sciences and Veterinary Medicine Cluj-Napoca, Romania, using selected Cyclamen species (fall blooming C. africanum Boiss \& Reut (African cyclamen), C. cyprium Schott \& Kotschy (Cyprus cyclamen), C. hederifolium Aiton 'Alba' (ivy-leaved cyclamen), C. mirabile Hildebr (sowbread) and spring blooming C. pseudibericum Hildebr (false Iberian cyclamen)). Cyclamen seeds (dry, not fresh) were purchased from various botanical gardens in Europe, namely: C. africanum, C. cyprium, C. hederifolium 'Alba' were purchased from Botanic Gardens and Arboretum of Mendel University of Agriculture and Forestry from the Czech Republic, Brno. C. mirabile and C. pseudibericum were purchased from Friedrich Schiller Universität Jena, Institut für Ökologie und Evolution, Botanischer Garten Jena, Germany. 


\subsection{Experiment Design and $G A_{3}$ Application on Selected Cyclamen Species}

The first experiment consisted of soaking of the Cyclamen seeds in different concentrations of $\mathrm{GA}_{3}$ (control, $50 \mathrm{mg} / \mathrm{L}, 100 \mathrm{mg} / \mathrm{L}, 150 \mathrm{mg} / \mathrm{L}$ ) in order to evaluate the germination of the selected Cyclamen species.

Seeds were surface sterilized (4.0\% sodium hypochlorite solution) for $15 \mathrm{~min}$ at room temperature followed by triple-rinsing with distilled sterile water. They were placed on cotton pads and covered with two layers of Whatman filter paper no. 1 in $9 \mathrm{~cm}$ Petri dishes, with $10 \mathrm{~mL}$ of distilled water and gibberellic acid $\left(\mathrm{GA}_{3}\right)$ on 10th June 2018. Petri dishes were kept at $65 \%$ humidity and alternating temperatures of $23-25^{\circ} \mathrm{C}$ with a photoperiod of $15-16 \mathrm{~h}$ light (day) and 8-9 $\mathrm{h}$ (night) for the long-day exposure treatment and of 5-6 h light and 17-18 h dark for the short-day exposure treatment. After 5 weeks on 18th July the seeds started to germinate. The seedlings were transplanted into pots $\left(14 \times 13 \mathrm{~cm}\right.$ in diameter) and watering with and without $\mathrm{GA}_{3}$ solution was carried out on the basis of plant requirements (4 days interval). The growing substrate $(60 / 20 / 20 \mathrm{v} / \mathrm{v})$ was a mixture of sowing and propagation soil $(\mathrm{pH}=6.0)$ with a content of $\mathrm{N} 0.1 \mathrm{~m} / \mathrm{m} \%, \mathrm{P}_{2} \mathrm{O}_{5} 0.01 \mathrm{~m} / \mathrm{m} \%, \mathrm{~K}_{2} \mathrm{O} 0.03 \mathrm{~m} / \mathrm{m} \%$, Cyclamen substrate ( $\mathrm{pH}=6.2$ ) with a content of $\mathrm{N} 1.0 \mathrm{~m} / \mathrm{m} \%, \mathrm{P}_{2} \mathrm{O}_{5} 0.1 \mathrm{~m} / \mathrm{m} \%, \mathrm{~K}_{2} \mathrm{O} 0.3 \mathrm{~m} / \mathrm{m} \%$, containing $70 \%$ organic substances and perlite.

The influence of exposure to short and long day condition $\left(\mathrm{GA}_{3}\right)$ on morphological parameters was evaluated. The plants were germinated at $24 \pm 1{ }^{\circ} \mathrm{C}$ in approximately 60 days, with two distinct photoperiod regimes: long-day exposure $(\sim 14 \mathrm{~h} \mathrm{light} / 10 \mathrm{~h}$ dark $)$ and short-day exposure $(\sim 6 \mathrm{~h} \mathrm{light} / 18 \mathrm{~h}$ dark). The intensity of the brightness was measured every two-three days using a luxmeter (Testo 440, Turda, Romania). The average of the greenhouse recordings at the end of the experiment were $842.2 \mu \mathrm{mol} \mathrm{m} \mathrm{s}^{-1}$, and for the shaded plants $147.6 \mu \mathrm{mol} \mathrm{m} \mathrm{m}^{2}$.

\subsection{Effect of Exogenous $\mathrm{GA}_{3}$ on Morphological and Physiological Traits Under Different Light Exposure Treatments}

Germinated seeds were counted every three days; a seed was considered as germinated at the moment of radicle protrusion. At the end of the experiments (day 65) multiple germination parameters were calculated; in addition, all germinated and non-germinated seeds were scanned and the ImageJ Programme 1.52a, Wayne Rasband, National Institutes of Health Bethesda, Maryland, USA for image processing was used to measure plant height, radical and petiole lengths $(\mathrm{cm})$, leaf area and tuber diameter $\left(\mathrm{cm}^{2}\right)$. Ten different germination parameters were assessed.

The germination percentage [25] was calculated using the method described by the Equation (1).

$$
G P=\Sigma U s / G s \times 100 \%
$$

where $U s$ is the number of seeds used and Gs in the final number of germinated seeds. To assess germination velocity $[24,25]$, mean germination time (MGT) was calculated using the method described by the Equation (2).

$$
M G T=\Sigma D n / \Sigma n
$$

where $D$ is the days from the beginning of the germination test, and $\mathrm{n}$ is the number of seeds newly germinated on day D [26]. The Seedling Vigour Index (SVI) [24] was calculated using the Equation (3):

$$
S V I=G P \times(M r+M h)
$$

where GP is the germination percentage, $M r$ is the mean root length ( $\mathrm{mm}$ ) and $\mathrm{Mh}$ is the Mean hypocotyl length (mm), as described by Abdul-Baki \& Anderson [27]. The following parameters used: mean germination rate (MGR) [24], coefficient of velocity (CV) [24], germination rate index (GRI) [28], germination index (GI) [29], Timson's germination index (TGI) [30], germination energy (GE) [30] and emergence index (EI) [31] did not have significant differences. 


\subsection{Statistical Analysis}

For each randomized block (four blocks in total), 5 plants per treatment were used (a total of 20 plants per exposure treatment). The aggregated dataset comprises 5 genotypes of 200 plants (80 control and 120 stress), along with ten germination parameters and five morpho-agronomic traits. The significance of the differences between treatments was tested by applying a one-way analysis of variance (ANOVA), at a confidence level of $95 \%$. When the ANOVA null hypothesis was rejected, Tukey's Post hoc test was carried out to establish the statistically significant differences at $p<0.05$.

\section{Results}

\subsection{Variation in Germination Parameters with Gibberellic Acid $\left(G A_{3}\right)$ Application Under Long-Day Exposure}

The morpho-agronomic traits monitored revealed that $\mathrm{GA}_{3}$ treatments positively influenced plant growth in long day condition. Comparing our results, these traits greatly differ depending on species, the germination power of the seeds and $\mathrm{GA}_{3}$ administered concentrations (data not shown).

As the usage of multiple germination parameters, such as the MGR, CV, GRI, TGI, GE and EI did not have significant differences (data not shown), we selected the GP, MGT and SVI which provide reliable information regarding seedling development. Compared with the water treatment, the most optimal $\mathrm{GA}_{3}$ rate increased the germination percentage (GP) by 13.33 and $40.33 \%$ with long-day exposure, in C. africanum, and C. hederifolium, respectively (Figure 1). At the concentration of $150 \mathrm{mg} / \mathrm{L}$, the seeds of C. africanum, C. cyprium, C. mirabile, and C. pseudibericum did not germinate (Figure 1A-D). In C. africanum, the level of administered $\mathrm{GA}_{3}$ prolonged the germination period but the plants developed better compared to control (Figure 1A).
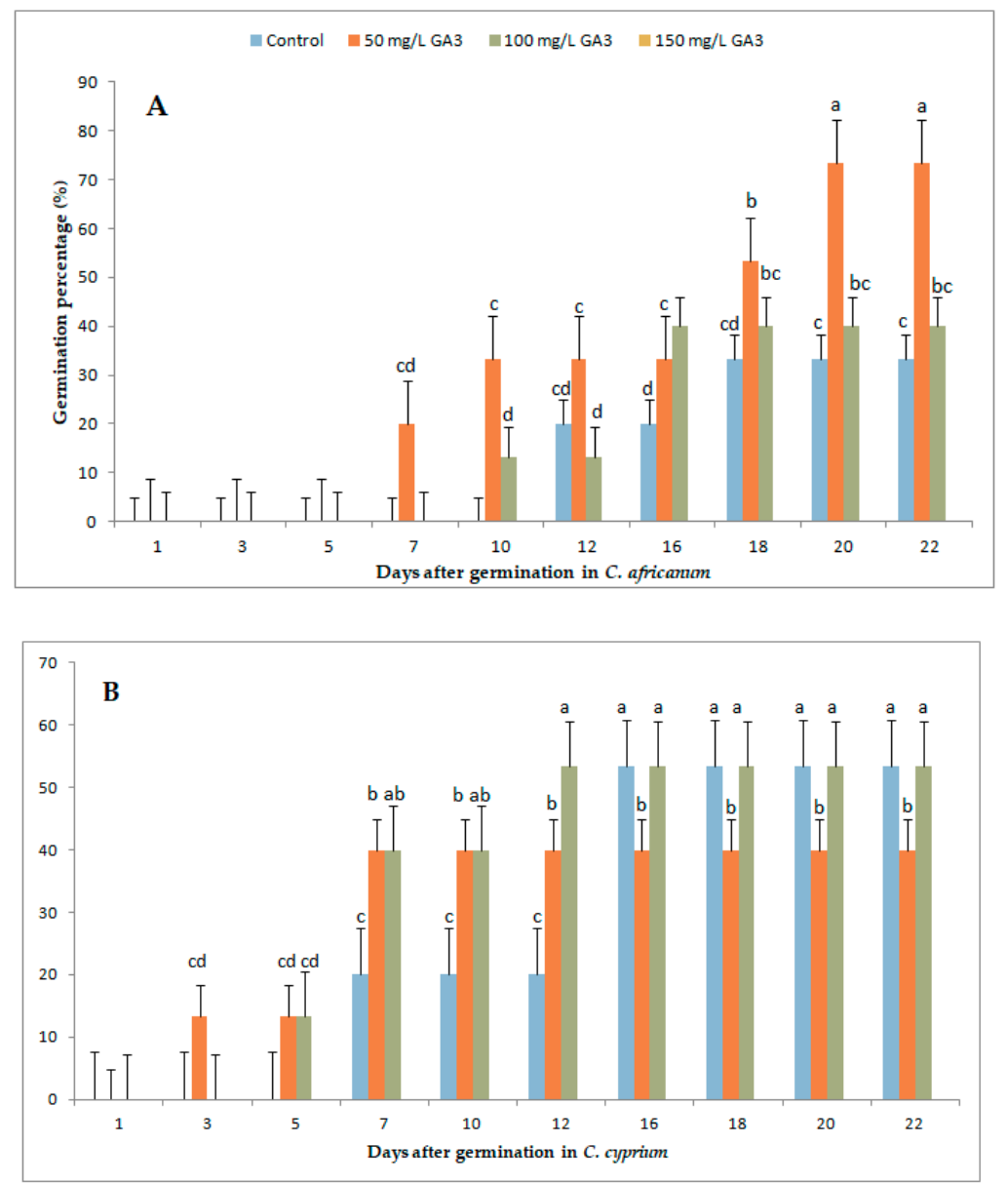

Figure 1. Cont. 

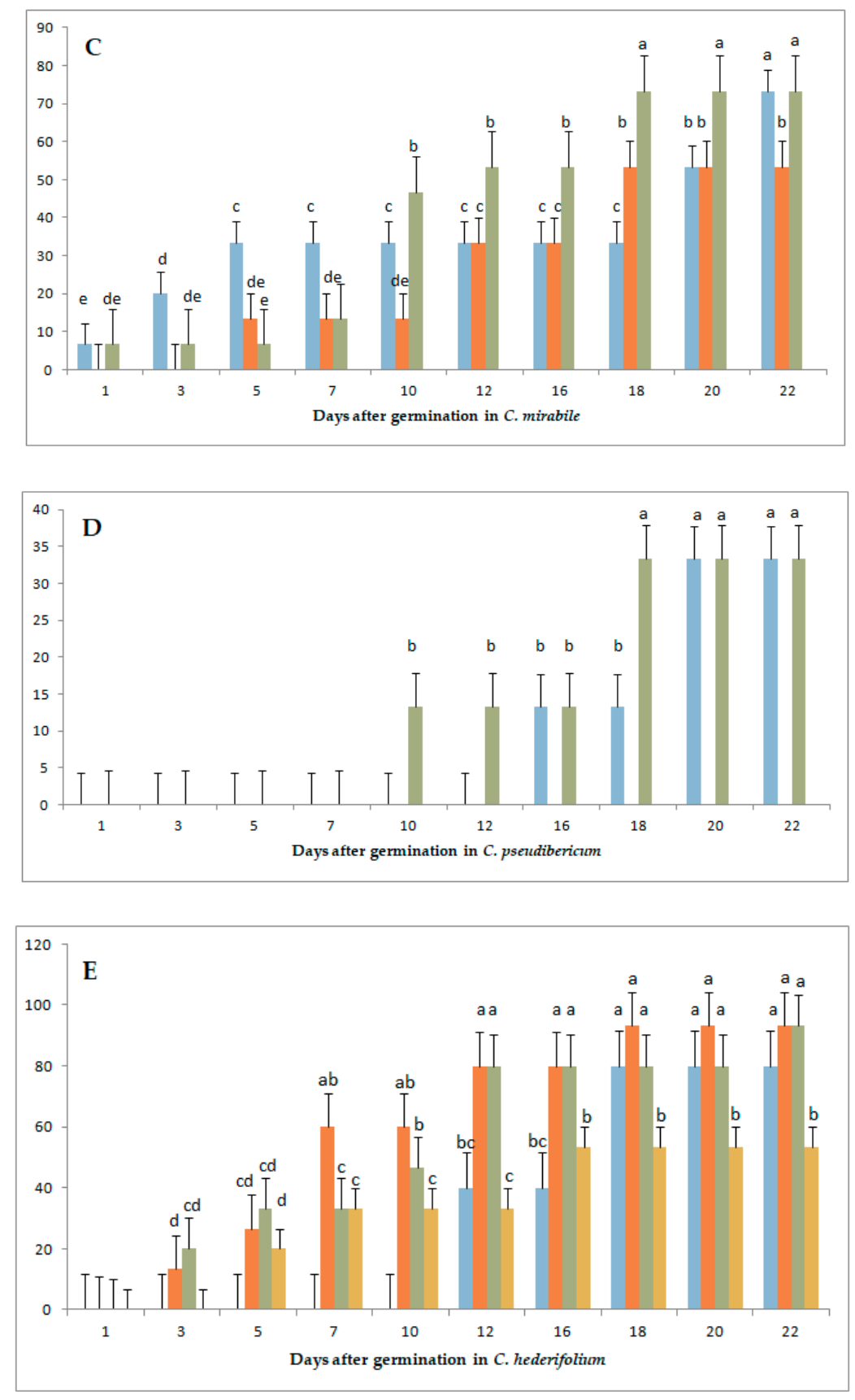

Figure 1. Effect of gibberellic acid (50,100, and $150 \mathrm{mg} / \mathrm{L} \mathrm{GA}_{3}$ ) and long-day exposure on germination percentage/day \pm SE of selected Cyclamen species: (A) Cyclamen africanum (African cyclamen); (B) Cyclamen cyprium (Cyprus cyclamen); (C) Cyclamen mirabile (sowbread); (D) Cyclamen pseudibericum (false Iberian cyclamen); (E) Cyclamen hederifolium 'Alba' (ivy-leaved cyclamen). Values (mean \pm SE) followed by different letters are significantly different based on Tukey's HSD (honestly significant difference) test at $p<0.05$.

In C. africanum the level of administered $\mathrm{GA}_{3}$ prolonged the germination period, but the plant developed better compared to the control. The $50 \mathrm{mg} / \mathrm{L}$ concentration administered proved to be favorable for both seed germination and seedling development, with a germination percentage of $80 \%$. At the concentration of $100 \mathrm{mg} / \mathrm{L}$, the plants developed similar to those of the control, the only difference being the early germination of seeds treated with $\mathrm{GA}_{3}$ (Figure $1 \mathrm{~A}$ ).

Germination occurred faster in C. cyprium compared to C. africanum. Although the germination percentage was not high $(60 \%)$, the most beneficial concentration in terms of seedling development was 
$100 \mathrm{mg} / \mathrm{L}$ which was similar to the control. When $\mathrm{GA}_{3}$ was administered at a concentration of $50 \mathrm{mg} / \mathrm{L}$, the seeds germinated the earliest, but with a weaker development. When $\mathrm{GA}_{3}$ was administered at a concentration of $50 \mathrm{mg} / \mathrm{L}$, the seeds germinated the earliest, but the petiole and tuber had a weaker development. At the concentration of $150 \mathrm{mg} / \mathrm{L}$ the seeds did not germinate, as in the case of C. africanum specie.

Regarding C. pseudibericum, the germination percentage showed no significant differences. At the concentrations of 50 and $150 \mathrm{mg} / \mathrm{L}$ the germination rate was $0 \%$. In contrast, the concentration of $100 \mathrm{mg} / \mathrm{L}$ proved to be effective both in terms of germination and plant development, although the germination percentage was quite low (40\%). Compared to the control, the concentration of $100 \mathrm{mg} / \mathrm{L}$ was similar in germination and plant development.

The highest germination percentage of $C$. mirabile was noticed in the case of untreated seeds, respectively in the case of seeds treated with a concentration of $100 \mathrm{mg} / \mathrm{L}(80 \%)$. The earliest germination was observed in the case of $100 \mathrm{mg} / \mathrm{L}$ concentration, although the plant had a weaker development. At the concentration of $50 \mathrm{mg} / \mathrm{L}$, the GP was low with a poor development of the plants.

In C. hederifolium 'Alba' the earliest germination was observed was observed with $50 \mathrm{mg} / \mathrm{L}$, which proved to be the most favorable in terms of germination percentage and plant development. In comparison, the concentration of $100 \mathrm{mg} / \mathrm{L}$ had similar results, the only difference being a slightly weaker development compared to the concentration of $50 \mathrm{mg} / \mathrm{L}$. At the concentration of $150 \mathrm{mg} / \mathrm{L}$ the germination percentage was the lowest, compared to the control, as well as a late development.

\subsection{Variation in Plant Growth and Morpho-Agronomic Parameters of Species Under Long-Day exposure}

Although the percentage of germination was low in most species, the period required for germination showed significant differences depending on the concentration of $\mathrm{GA}_{3}$ administered (data not shown). Seed of $C$. cyprium showed the greatest germination percentage with control condition (water germination) which were reduced with $50 \mathrm{mg} / \mathrm{L} \mathrm{GA}_{3}$ (Table 1). Comparatively, C. africanum and C. hederifolium 'Alba'; had a higher germination percentage with $100 \mathrm{mg} / \mathrm{L}$. C. pseudibericum had the lowest germination percentage of all the species. In the case of $C$. africanum, the highest percentage of germination was observed at the administered concentration of $50 \mathrm{mg} / \mathrm{L}$. In the C. cyprium species, concentrations of 50 and $100 \mathrm{mg} / \mathrm{L}(36 \%)$ gave better results than the lower $\mathrm{GA}_{3}$ concentration of $50 \mathrm{mg} / \mathrm{L}$. In the case of $C$. mirabile the germination percentage was decreased by higher concentrations of $\mathrm{GA}_{3}$ (Table 1).

The period of time required for germination under control corresponded approximately to the percentage of germination, with the highest values (lowest MGT) calculated for the species C. cyprium, C. mirabile and C. hederifolium 'Alba'(64-66 days) and higher MGT, between 77 and 81 days, for C. africanum and C. pseudibericum, respectively. Increased concentration of $\mathrm{GA}_{3}$ generally led to a significant decrease in MGT (increased germination rate), except for C. cyprium, which showed a reduction in MGT (increased germination rate) of $47 \%$ at the concentration of $50 \mathrm{mg} / \mathrm{L}$. Comparatively, the lowest MGT value was recorded in C. hederifolium 'Alba', $20 \%$ at the concentration of $100 \mathrm{mg} / \mathrm{L}$, being the species with the highest germination rate. Good results were also recorded at a concentration of $150 \mathrm{mg} / \mathrm{L}$. With the species C. mirabile and C. hederifolium 'Alba', the lowest value of MGT was recorded at concentrations of $100(43 \%)$ and $50 \mathrm{mg} / \mathrm{L}(56 \%)$. Compared to control, the plants of C. pseudibericum at $100 \mathrm{mg} / \mathrm{L} \mathrm{GA}_{3}$ concentration required a greater period for germination, with a MGT value of $54 \%$ (Table 1 ).

The SVI of the Cyclamen accessions was significantly affected by $\mathrm{GA}_{3}$ application and was enhanced with increasing $\mathrm{GA}_{3}$ (Table 2). The highest SVI was observed in C. mirabile with $\mathrm{GA}_{3}$ application $(100 \mathrm{mg} / \mathrm{L})$ followed by C. cyprium and C. hederifolium. (50 mg/L and $100 \mathrm{mg} / \mathrm{L}$, respectively) compared to that of control. Moreover, a significant difference was found in the SVI of different accessions, and the SVI of C. mirabile at $100 \mathrm{mg} / \mathrm{L} \mathrm{GA}_{3}$ was remarkably higher than that $\mathrm{C}$. africanum and C. pseudibericum at the administered $\mathrm{GA}_{3}$ concentration of $100 \mathrm{mg} / \mathrm{L}$, which had a lower SVI (82.6 and 100.4, respectively). The variation in SVI might be attributed to improved germination which depends 
upon the roots and shoots length of the seedlings, as well as stimulation of enzymatic activities. The results are in accordance with the findings of Kumar et al. (2018) [32] who reported significant increase in SVI of coriander (Coriandrum sativum L. (Chinese parsley)) with the application of $\mathrm{GA}_{3}$.

Table 1. Effects of increasing $\mathrm{GA}_{3}$ concentrations $(\mathrm{mg} / \mathrm{L})$ on the indicated seed germination parameters of the five selected Cyclamen taxa.

\begin{tabular}{|c|c|c|c|c|c|}
\hline \multirow[t]{2}{*}{ Parameter } & \multirow[t]{2}{*}{ Genotype } & \multicolumn{4}{|c|}{$\mathrm{GA}_{3}$ Concentrations $(\mathrm{mg} / \mathrm{L})$} \\
\hline & & 0 & 50 & 100 & 150 \\
\hline \multirow{5}{*}{$\begin{array}{l}\text { Germination } \\
\text { percentage } \\
(\mathrm{GP} \%)\end{array}$} & C. africanum (African cyclamen) & $33.33 \pm 0.76 c$ & $73.33 \pm 0.8 \mathrm{a}$ & $40.00 \pm 1.0 \mathrm{~b}$ & $0.0 \pm 0.0 \mathrm{~d}$ \\
\hline & C. cyprium (Cyprus cyclamen) & $53.33 \pm 0.8 \mathrm{a}$ & $40.00 \pm 0.9 \mathrm{~b}$ & $53.33 \pm 0.7 \mathrm{ac}$ & $0.0 \pm 0.0 \mathrm{c}$ \\
\hline & C. hederifolium 'Alba' (ivy-leaved cyclamen) & $80.00 \pm 0.7 \mathrm{~b}$ & $93.33 \pm 0.8 \mathrm{a}$ & $93.33 \pm 0.76 a$ & $53.33 \pm 0.8 c$ \\
\hline & C. mirabile (sowbread) & $73.33 \pm 0.8 \mathrm{a}$ & $53.33 \pm 0.7 \mathrm{~b}$ & $73.33 \pm 0.8 \mathrm{a}$ & $0.00 \pm 0.0 \mathrm{c}$ \\
\hline & C. pseudibericum Hildebr (false Iberian cyclamen) & $0.00 \pm 0.0 \mathrm{~b}$ & $33.33 \pm 0.76 \mathrm{a}$ & $0.00 \pm 0.0 \mathrm{~b}$ & $33.33 \pm 0.8 \mathrm{a}$ \\
\hline \multirow{5}{*}{$\begin{array}{c}\text { Mean } \\
\text { germination } \\
\text { time-MGT } \\
\text { (days) }\end{array}$} & C. africanum (African cyclamen) & $33.62 \pm 1.2 \mathrm{c}$ & $23.90 \pm 0.7 b$ & $42.72 \pm 1.5 \mathrm{~d}$ & $0.00 \pm 0.0 \mathrm{a}$ \\
\hline & C. cyprium (Cyprus cyclamen) & $31.22 \pm 0.8 c$ & $47.50 \pm 1.0 \mathrm{~d}$ & $32.70 \pm 0.9 b$ & $0.00 \pm 0.0 \mathrm{a}$ \\
\hline & C. hederifolium 'Alba' (ivy-leaved cyclamen) & $49.22 \pm 1.3 \mathrm{~d}$ & $29.36 \pm 0.9 b$ & $19.57 \pm 0.4 \mathrm{a}$ & $32.07 \pm 0.6 \mathrm{c}$ \\
\hline & C. mirabile (sowbread) & $73.59 \pm 2.8 b$ & $55.64 \pm 1.4 \mathrm{~d}$ & $43.32 \pm 0.4 c$ & $0.00 \pm 0.0 \mathrm{a}$ \\
\hline & C. pseudibericum (false Iberian cyclamen) & $37.51 \pm 1.9 \mathrm{~b}$ & $0.00 \pm 0.0 \mathrm{a}$ & $53.9 \pm 1.8 \mathrm{c}$ & $0.00 \pm 0.0 \mathrm{a}$ \\
\hline \multirow{5}{*}{$\begin{array}{l}\text { Seedling vigor } \\
\text { index I (SVI) }\end{array}$} & C. africanum (African cyclamen) & $20.0 \pm 2.6 b$ & $185.5 \pm 2.7 \mathrm{~d}$ & $82.6 \pm 4.2 \mathrm{c}$ & $0.0 \pm 0.0 \mathrm{a}$ \\
\hline & C. cyprium (Cyprus cyclamen) & $190.8 \pm 3.2 b$ & $223.8 \pm 3.2 c$ & $346.4 \pm 4.0 \mathrm{~d}$ & $0.0 \pm 0.0 \mathrm{a}$ \\
\hline & C. hederifolium 'Alba' (ivy-leaved cyclamen) & $114.8 \pm 2.3 b$ & $328.2 \pm 3.2 \mathrm{~d}$ & $312.4 \pm 2.9 \mathrm{c}$ & $110.4 \pm 2.6 \mathrm{a}$ \\
\hline & C. mirabile (sowbread) & $461.9 \pm 3.0 \mathrm{c}$ & $187.3 \pm 3.7 \mathrm{~b}$ & $812.4 \pm 2.5 \mathrm{~d}$ & $0.0 \pm 0.0 \mathrm{a}$ \\
\hline & C. pseudibericum (false Iberian cyclamen) & $63.6 \pm 2.2 b$ & $0.0 \pm 0.0 \mathrm{a}$ & $100.4 \pm 1.9 c$ & $0.0 \pm 0.0 \mathrm{a}$ \\
\hline
\end{tabular}

Values are means \pm SE. Different lowercase letters denote significant differences under different treatments based on genotype at the 0.05 probability level according to the Tukey's HSD test.

Table 2. Effects of increasing $\mathrm{GA}_{3}$ concentrations $(\mathrm{mg} / \mathrm{L})$ on the indicated seed germination parameters of the five selected Cyclamen taxa.

\begin{tabular}{|c|c|c|c|c|c|}
\hline \multirow[t]{2}{*}{ Parameter } & \multirow[t]{2}{*}{ Genotype } & \multicolumn{4}{|c|}{$\mathrm{GA}_{3}$ Concentrations $(\mathrm{mg} / \mathrm{L})$} \\
\hline & & $0 \mathrm{GA}_{3}$ & $50 \mathrm{GA}_{3}$ & $100 \mathrm{GA}_{3}$ & $150 \mathrm{GA}_{3}$ \\
\hline \multirow{5}{*}{$\begin{array}{c}\text { Germination } \\
\text { percentage } \\
(\mathrm{GP} \%)\end{array}$} & C. africanum & $33.33 \pm 0.75 b$ & $0.00 \pm 0.0 \mathrm{c}$ & $73.33 \pm 0.7 \mathrm{a}$ & $33.33 \pm 0.8 \mathrm{~b}$ \\
\hline & C. cyprium & $33.33 \pm 0.8 b$ & $73.33 \pm 1.0 \mathrm{a}$ & $73.33 \pm 0.76 a$ & $73.33 \pm 1.0 \mathrm{a}$ \\
\hline & C. hederifolium "'Alba' & $33.33 \pm 1.2 \mathrm{~d}$ & $93.33 \pm 0.7 \mathrm{a}$ & $73.33 \pm 0.8 b$ & $60.00 \pm 1.1 \mathrm{c}$ \\
\hline & C. mirabile & $93.33 \pm 0.7 \mathrm{a}$ & $93.33 \pm 0.8 \mathrm{a}$ & $53.33 \pm 0.76 a$ & $53.33 \pm 0.8 \mathrm{a}$ \\
\hline & C. pseudibericum & $53.33 \pm 0.75 a$ & $0.00 \pm 0.0 \mathrm{~b}$ & $53.33 \pm 0.8 \mathrm{a}$ & $0.00 \pm 0.0 \mathrm{~b}$ \\
\hline \multirow{5}{*}{$\begin{array}{l}\text { Mean } \\
\text { germination } \\
\text { time-MGT } \\
\text { (days) }\end{array}$} & C. africanum & $64.3 \pm 0.4 b$ & $0.0 \pm 0.0 \mathrm{~d}$ & $13.9 \pm 0.6 \mathrm{a}$ & $37.6 \pm 1.9 \mathrm{c}$ \\
\hline & C. cyprium & $34.4 \pm 0.7 \mathrm{~d}$ & $74.4 \pm 1.4 \mathrm{a}$ & $33.2 \pm 0.9 \mathrm{c}$ & $47.7 \pm 1.2 \mathrm{~b}$ \\
\hline & C. hederifolium 'Alba' & $41.3 \pm 0.8 \mathrm{a}$ & $26.1 \pm 0.4 \mathrm{c}$ & $30.5 \pm 0.7 \mathrm{~b}$ & $30.7 \pm 0.4 b$ \\
\hline & C. mirabile & $28.3 \pm 0.7 \mathrm{c}$ & $50.8 \pm 0.9 \mathrm{a}$ & $38.6 \pm 0.4 b$ & $51.7 \pm 0.6 \mathrm{a}$ \\
\hline & C. pseudibericum & $35.4 \pm 1.9 \mathrm{a}$ & $0.0 \pm 0.0 c$ & $23.2 \pm 1.4 \mathrm{~b}$ & $23.9 \pm 1.4 \mathrm{~b}$ \\
\hline \multirow{5}{*}{$\begin{array}{l}\text { Seedling vigor } \\
\text { index I (SVI) }\end{array}$} & C. africanum & $206.4 \pm 1.5 \mathrm{a}$ & $0.0 \pm 0.0 \mathrm{~d}$ & $178.0 \pm 3.4 \mathrm{c}$ & $134.4 \pm 2.2 \mathrm{~b}$ \\
\hline & C. cyprium & $1123.8 \pm 0.6 \mathrm{a}$ & $417.8 \pm 0.5 \mathrm{~d}$ & $611.6 \pm 0.4 b$ & $517.9 \pm 0.8 c$ \\
\hline & C. hederifolium 'Alba' & $143.5 \pm 0.8 \mathrm{~d}$ & $304.8 \pm 0.1 \mathrm{a}$ & $234.9 \pm 0.4 b$ & $198.2 \pm 0.3 c$ \\
\hline & C. mirabile & $640.9 \pm 0.3 \mathrm{a}$ & $577.0 \pm 0.5 b$ & $456.8 \pm 0.7 c$ & $245.3 \pm 1.2 \mathrm{~d}$ \\
\hline & C. pseudibericum & $176.3 \pm 0.5 b$ & $0.0 \pm 0.0 \mathrm{~d}$ & $248.4 \pm 0.0 \mathrm{a}$ & $75.2 \pm 1.2 \mathrm{c}$ \\
\hline
\end{tabular}

Values shown are means $\pm \mathrm{SE}(n=3)$. For each parameter and accession, different lowercase letters in a row indicate significant differences between treatments according to Tukey's HSD test $(p<0.05)$

The plants' height was measured from the highest point of the leaf to the beginning of the tuber. Germination of C. pseudibericum was irregular and none of the Cyclamen species germinated when $150 \mathrm{mg} / \mathrm{L} \mathrm{GA}_{3}$ was applied (Figure 2). Height and petiole length of C. cyprium and C. mirabile was highest with $150 \mathrm{mg} / \mathrm{L} \mathrm{GA}_{3}$. Regarding the plants of $C$. africanum, elongation of the plant and petiole, as well as leaf area, tuber diameter, and radicle length were greatest with $50 \mathrm{mg} / \mathrm{L}$.

\subsection{Variation in Germination Parameters with Gibberellic Acid $\left(G A_{3}\right)$ Application and Short-Day Exposure}

Compared to long-day exposure, it was observed that the germination percentages differed greatly when species were exposed to $\mathrm{GA}_{3}$ and short days (data not shown). With short days, higher $\mathrm{GA}_{3}$ rates increased germination (Figure 3). In C. africanum, $\mathrm{GA}_{3}$ administration delayed germination and $100 \mathrm{mg} / \mathrm{L}$ had the greatest germination percentage. Unlike long days, at a concentration of $50 \mathrm{mg} / \mathrm{L}$ the seeds did not germinate having $0 \%$ germination percentage. The best concentration with regards 
to plant development was that of $100 \mathrm{mg} / \mathrm{L}$, being the concentration with the highest germination percentage, i.e., $80 \%$.

In C. cyprium, germination occurred faster than in the case of $C$. africanum all GA concentrations delayed germination. The most beneficial concentrations in terms of development were 100 and $150 \mathrm{mg} / \mathrm{L}$, while the concentration of $50 \mathrm{mg} / \mathrm{L}$ administered prolonged the period of germination. The germination rate of the seeds was affected by $\mathrm{GA}_{3}$ but not the germination percentage of $80 \%$.

The germination percentages in C. pseudibericum showed no significant differences, only in terms of plant development. At concentrations of $50 \mathrm{mg} / \mathrm{L}$ the germination percentage was $0 \%$. In contrast, the concentration of $100 \mathrm{mg} / \mathrm{L}$ increased both germination and plant development. Compared to the control, the concentration of $150 \mathrm{mg} / \mathrm{L}$ showed similarities regarding germination and plant development.

The highest germination percentage of $\mathrm{C}$. mirabile was in the case of seeds treated with $\mathrm{GA}_{3}$ at a concentration of $50 \mathrm{mg} / \mathrm{L}$, where the germination percentage reached $100 \%$. The earliest germination was observed in the case of 50 and $100 \mathrm{mg} / \mathrm{L}$, compared to control at which the germination took place later.

Regarding the species C. hederifolium 'Alba' the earliest germination was observed in the case of 50 and $150 \mathrm{mg} / \mathrm{L}$ concentrations. Also, the highest germination percentage was at 50 and $100 \mathrm{mg} / \mathrm{L}$ administration doses.
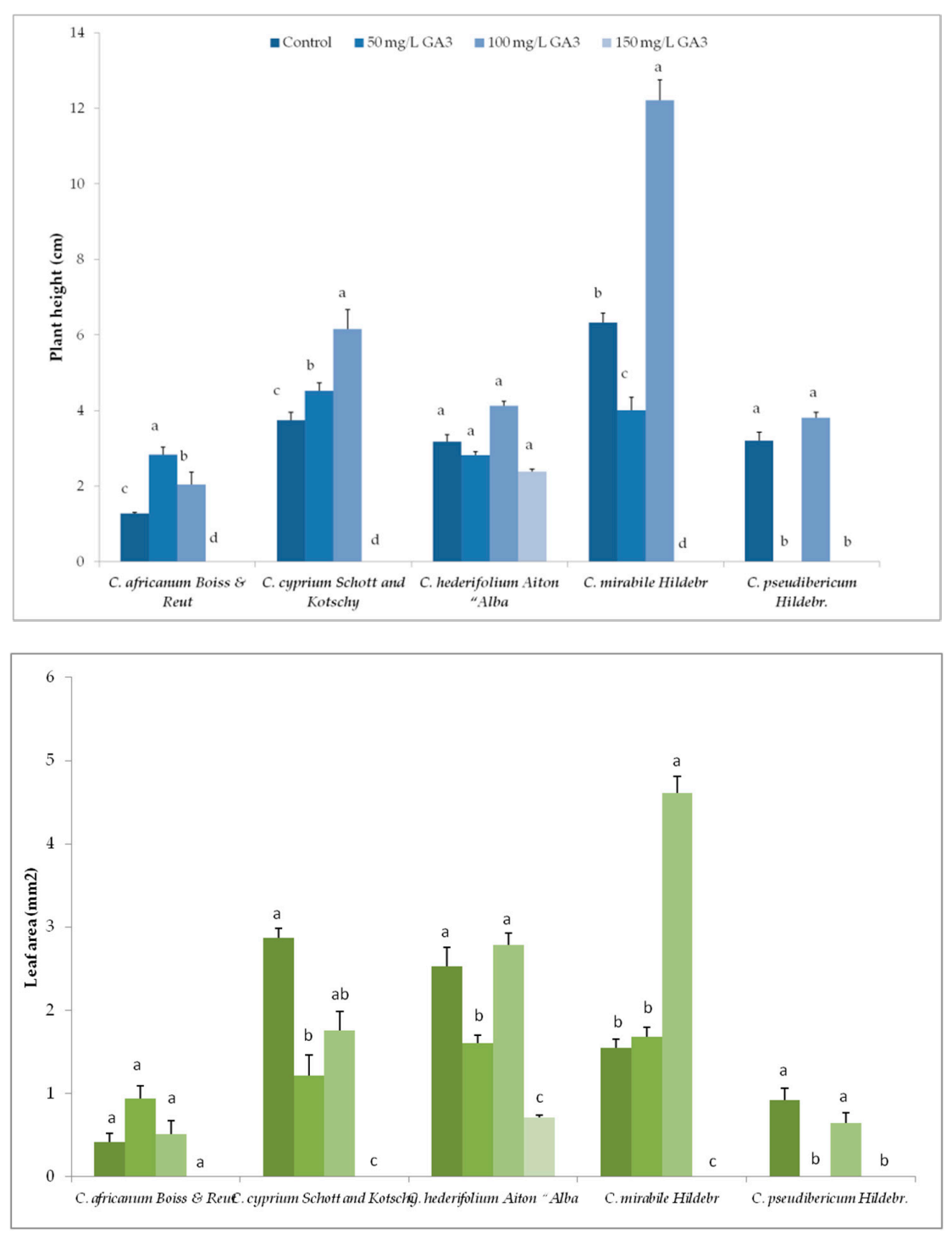

Figure 2. Cont. 

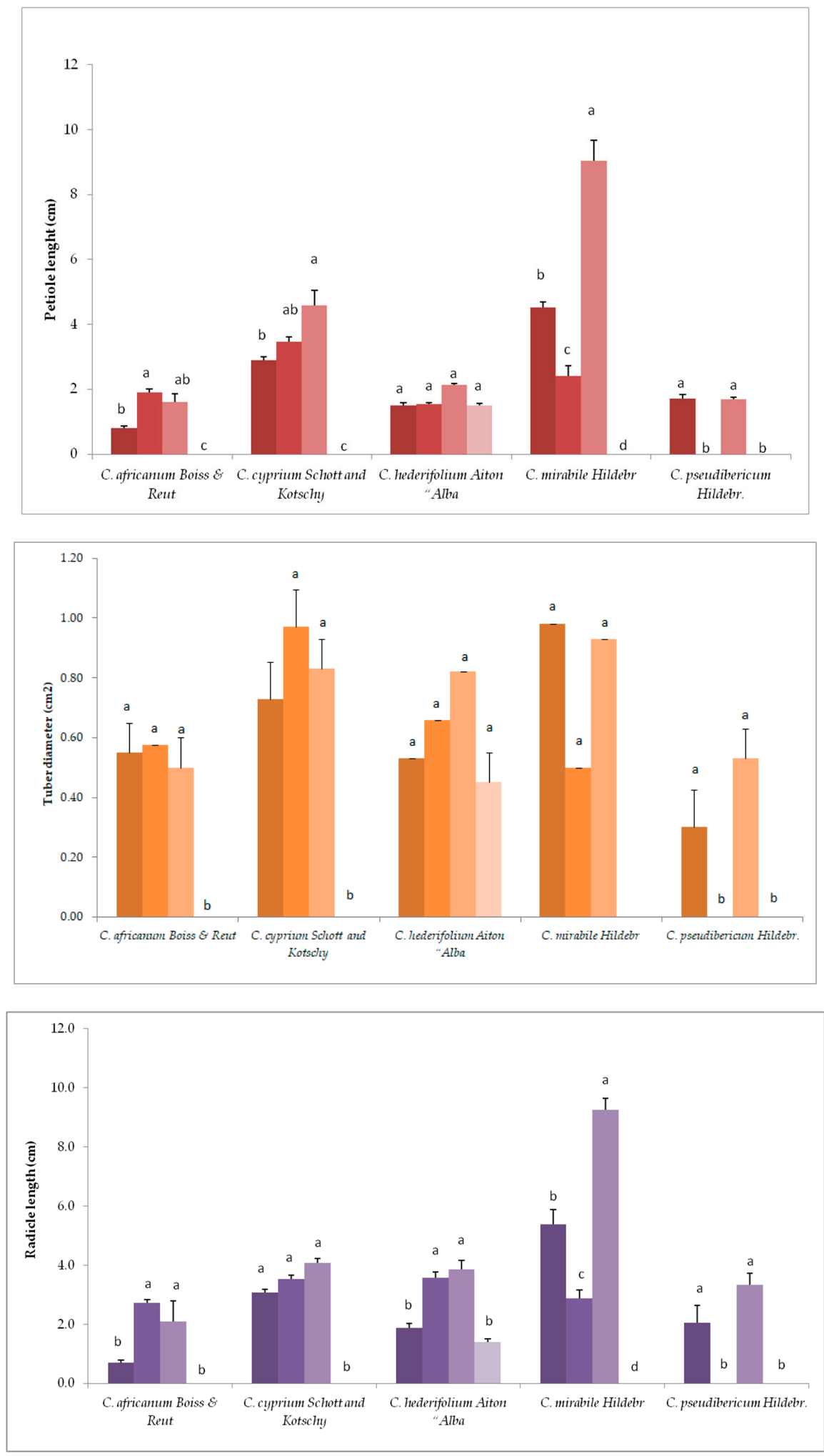

Figure 2. Variation of morphological parameters in Cyclamen species based on different concentration of gibberellic acid $\left(\mathrm{GA}_{3}\right)$. Different lowercase letters above the bars indicate significant differences between treatments, for each genotype, according to the Tukey's HSD test $(p<0.05)$. 


\subsection{Variation in Plant Growth and Morpho-Agronomic Parameters of Short-Day Exposed Cyclamen Species}

Seeds from Cyclamen species (C. cyprium and C. mirabile) showed high germination percentage (47.4-55.3\%) under control conditions (water germination). The 50 and $150 \mathrm{mg} / \mathrm{L} \mathrm{GA}$ treatments decreased the percentage of germination by $15.3-31.3 \%$ in C. cyprium and by $8.1-17.8 \%$ in C. mirabile. Comparatevely, $C$. hederifolium 'Alba' treated with $50 \mathrm{mg} / \mathrm{L} \mathrm{GA}_{3}$ had a higher germination percentage than the control. C. pseudibericum had the lowest germination percentage of the Cyclamen species but was higher with the $100 \mathrm{mg} / \mathrm{L} \mathrm{GA}_{3}$. In the case of $C$. africanum, the highest percentage of germination was observed in the presence of the concentration of $100 \mathrm{mg} / \mathrm{L}$ and with no germination at $50100 \mathrm{mg} / \mathrm{L}$ concentration. In the C. cyprium species, concentrations of 100 and $150 \mathrm{mg} / \mathrm{L}(42 \%)$ gave better results than the lower $\mathrm{GA}_{3}$ concentration of $50 \mathrm{mg} / \mathrm{L}$ (Table 2).

Although the percentage of germination was low in most species, the period required for germination showed significant differences depending on the concentration of $\mathrm{GA}_{3}$ administered (data not shown). The period required for germination under control corresponded approximately to the percentage of germination, with the highest values (lowest MGT) calculated for the species C. mirabile, C. hederifolium 'Alba' and C. cyprium (63-68 days) and higher MGT, between 65 and 81 days, for $C$. africanum, and C. pseudibericum, respectively (Table 2). Increased concentration of $\mathrm{GA}_{3}$ generally led to a significant decreased MGT (i.e., earlier germination), except for C. mirabile and C. cyprium, which showed an increase in MGT (delayed germination) of approx. $22.5-40.0 \%$ at the concentration of $50 \mathrm{mg} / \mathrm{L}$. Comparatively, the lowest MGT value was recorded in C. africanum Boiss \& Reut, $13.9 \%$ at the concentration of $100 \mathrm{mg} / \mathrm{L}$. With the species C. cyprium and C. hederifolium' Alba', the lowest value of MGT was recorded at concentrations of $100 \mathrm{mg} / \mathrm{L}(30.5-33.2 \%)$. For the species C. pseudibericum, all concentrations of $\mathrm{GA}_{3}$ took less time to germinate than the control with a MGT value of $23 \%$ at both 100 and $150 \mathrm{mg} / \mathrm{L}$ concentrations. The SVI of the Cyclamen accessions slightly decreased by $\mathrm{GA}_{3}$ application in the case of $C$. africanum, C. cyprium and C. mirabile (data not shown). The highest SVI was observed in C. cyprium on $\mathrm{GA}_{3}$ application $(100 \mathrm{mg} / \mathrm{L}$ and $150 \mathrm{mg} / \mathrm{L}$, respectively) followed by C. mirabile. ( $50 \mathrm{mg} / \mathrm{L}$ and $100 \mathrm{mg} / \mathrm{L}$, respectively) compared to that of control (Table 2). Moreover, a significant difference was found in the SVI of different accessions and the SVI of C. cyprium at $100 \mathrm{mg} / \mathrm{L} \mathrm{GA}_{3}$ was remarkably higher than that of $C$. africanum, C. hederifolium and C. pseudibericum which had a lower SVI (178.0, 234.9 and 148.4, respectively).

The plants' height was measured from the highest point of the leaf to the beginning of the tuber. According to Figure 4, the values show the existence of statistically significant differences. The concentration of $\mathrm{GA}_{3}$ to which the Cyclamen species had the most significant response in terms of elongation and plant development was $100 \mathrm{mg} / \mathrm{L}$.

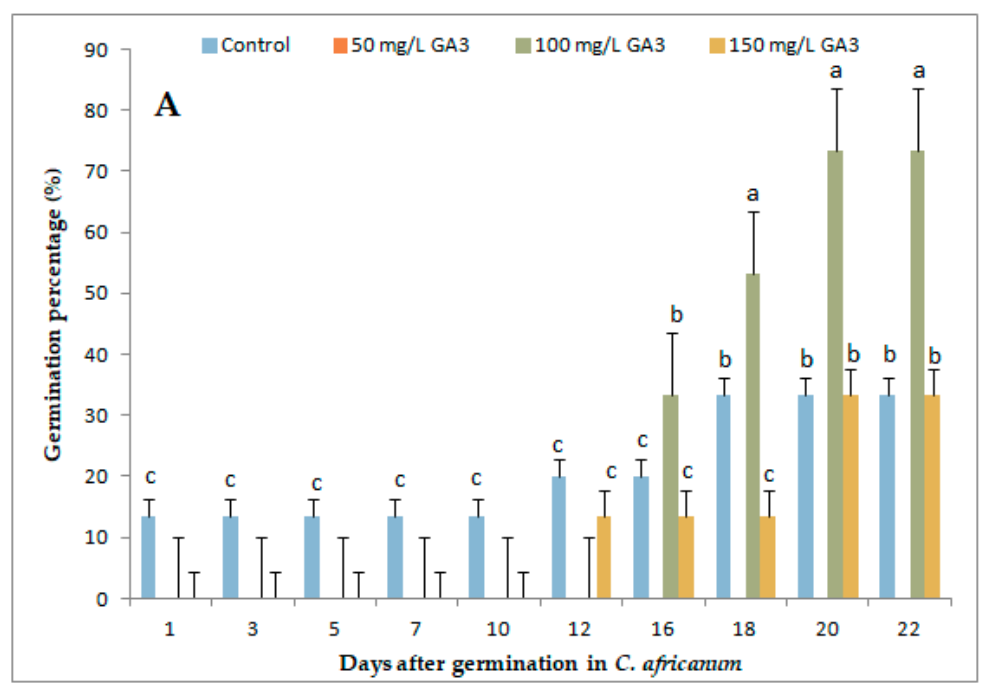

Figure 3. Cont. 

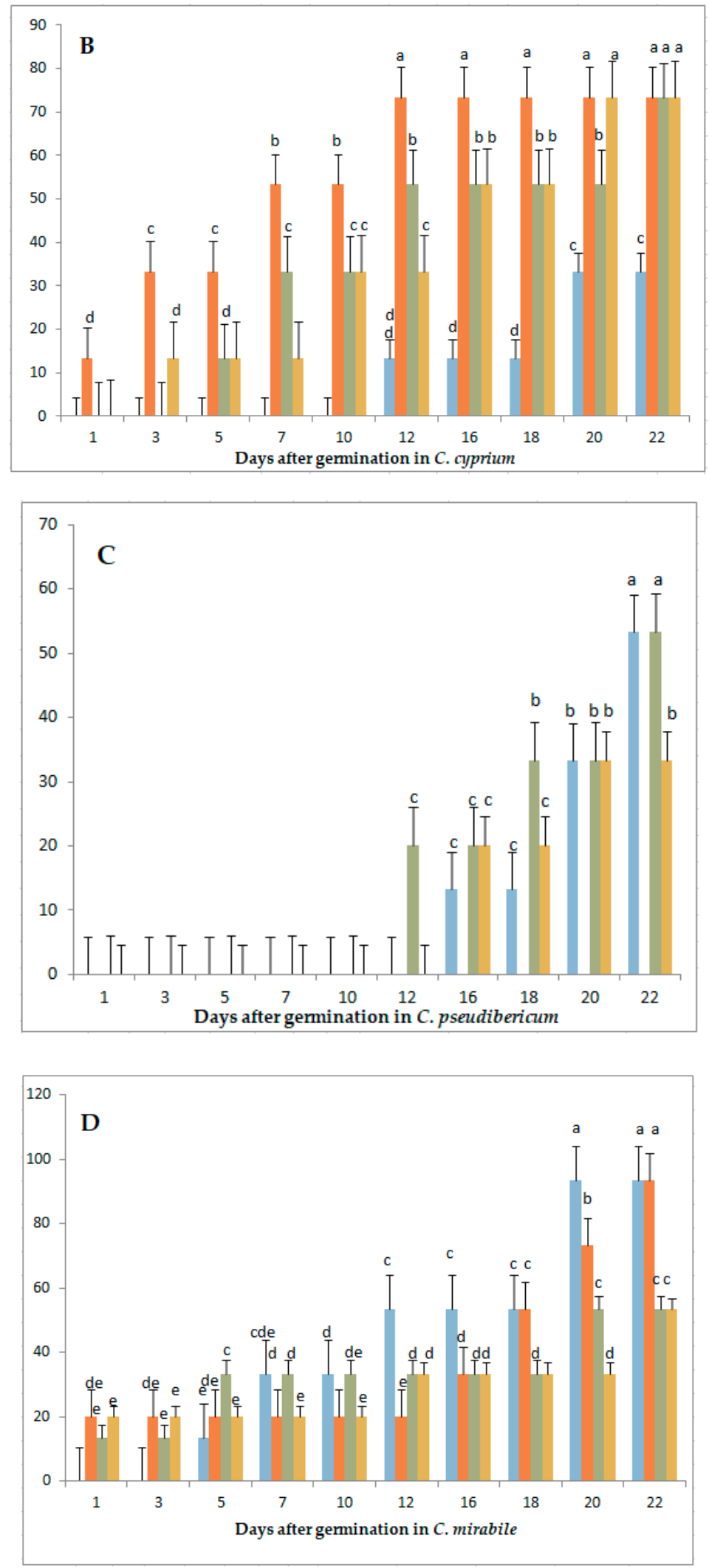

Figure 3. Cont. 


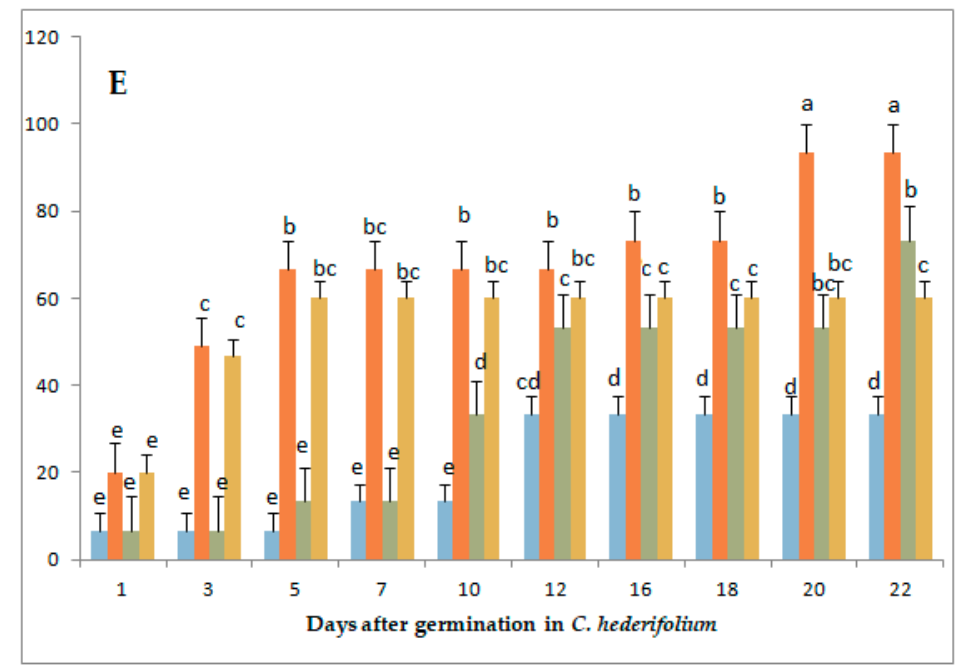

Figure 3. Effect of gibberellic acid (50, 100 and $150 \mathrm{mg} / \mathrm{L} \mathrm{GA}_{3}$ ) and short -day exposure on germination percentage/day $\pm \mathrm{SE}$ of selected Cyclamen species (A) Cyclamen africanum (African cyclamen); (B) Cyclamen cyprium (Cyprus cyclamen); (C) Cyclamen mirabile (sowbread); (D) Cyclamen pseudibericum (false Iberian Cyclamen); (E) Cyclamen hederifolium 'Alba' (ivy-leaved cyclamen). Values (mean $\pm \mathrm{SE}$ ) followed by different letters are significantly different based on Tukey's HSD test at $p<0.05$.

Except for C. africanum, in general, $\mathrm{GA}_{3}$ applied at $150 \mathrm{mg} / \mathrm{L}$ reduced the plant height, petiole length and tuber diameter, but increased the leaf area and radicle length. The $100 \mathrm{mg} / \mathrm{L} \mathrm{GA}_{3}$ increased the height, petiole length, and tuber diameter but decreased the leaf area and radicle length. Regarding the species C. africanum a major increase in height of the plant and elongation of the petiole as well as a slight increase in leaf area was observed at the concentration of $150 \mathrm{mg} / \mathrm{L}$. The tuber developed best at the concentration of $150 \mathrm{mg} / \mathrm{L}$ and the radicle at control. At the concentration of $50 \mathrm{mg} / \mathrm{L}$ the seeds did not germinate. Similar results regarding leaf area and plant height were recorded in Gazania rigens $\mathrm{L}$ (treasure flower) at $100 \mathrm{mg} / \mathrm{L} \mathrm{GA}_{3}$ concentrations [33].

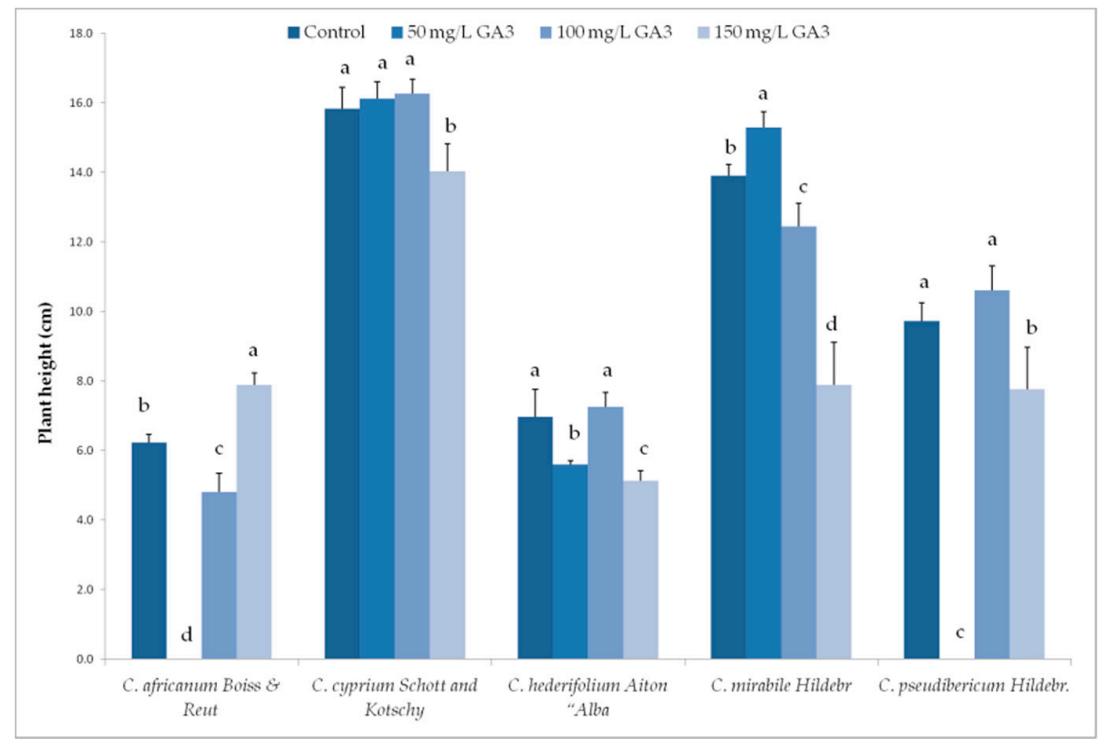

Figure 4. Cont. 

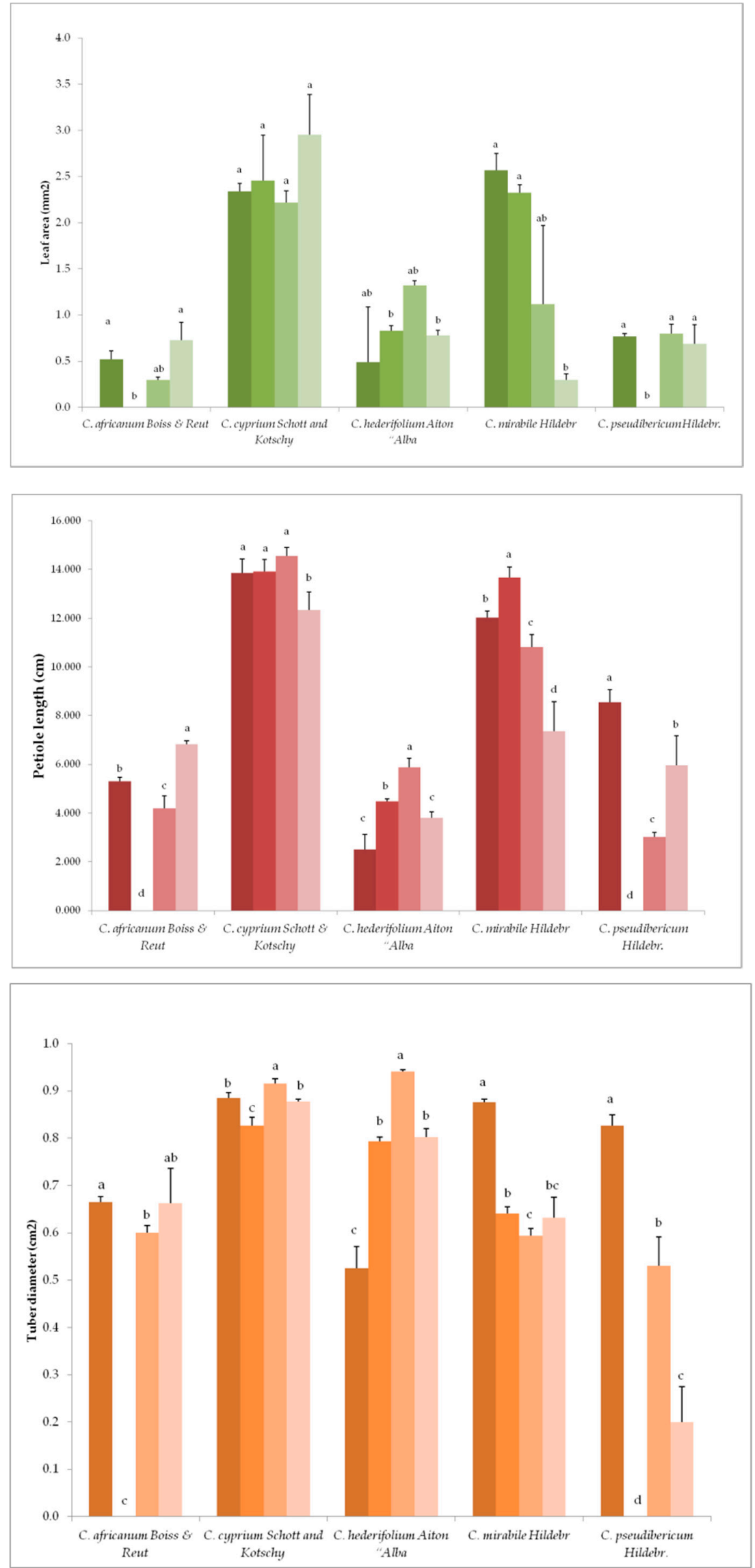

Figure 4. Cont. 


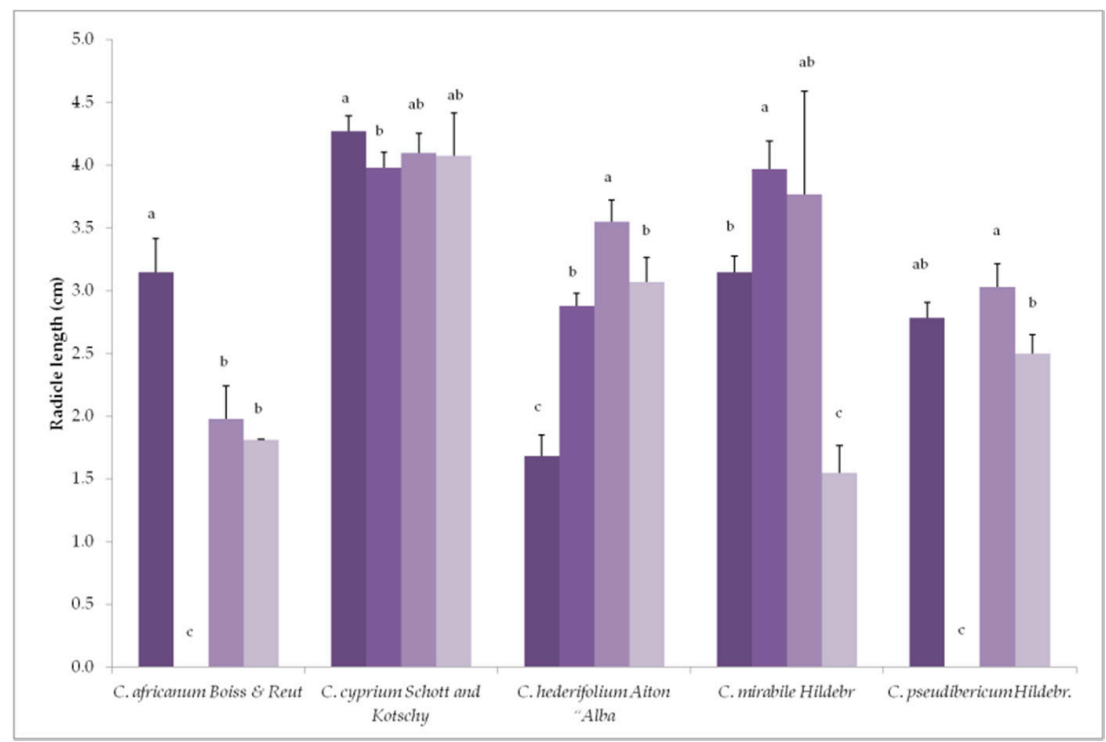

Figure 4. Variation of morphological parameters in Cyclamen species based on different concentration of gibberellic acid $\left(\mathrm{GA}_{3}\right)$. Different lowercase letters above the bars indicate significant differences between treatments, for each genotype, according to the Tukey's HSD test $(p<0.05)$.

\section{Discussion}

The results of this experiment showed that proper concentration of $\mathrm{GA}_{3}$ could significantly support seed germination and seedling growth of some Cyclamen species under different day length exposure. GA are extensively used in agriculture and horticulture as tools for boosting productivity, cost reduction and enhancing ornamental value of multiple plants. $\mathrm{GA}_{3}$ plays a role in seed germination, stem elongation, response to abiotic stress, flowering and fruit development. The effect of GA treatments depends on species, concentrations used and time of applications. Hanyan et al. 2006 [34], found that treatment with multiple concentrations of $\mathrm{GA}_{3}(20-400 \mathrm{mg} / \mathrm{L}$ enhanced seed germination, but with significant differences among the varieties of Cyclamen persicum used. Furthermore, the juvenile phase may last from only a few days in annual plants to several years in perennials [35], and depends on seed harvesting, especially in Cyclamen species, the age of the plant, number of leaves, or size of meristem.

The activity promoted by exogenous GA has been frequently reported in multiple studies. GAs led to the extension of the plant of peas [36], the increase of the internode to Ilex paraguariensis A.St.-Hil (yerba mate) [37], the elongation of the petiole to Thlaspi arvense L. (field pennycress) [38] and the elongation of Triticum aestivum L. (common wheat) leaves, respectively [39]. Recent advances highlight the importance of internal and external factors (amount of GA, short or long day exposure, developmental stage) which regulate the expression of FLOWERING LOCUS T gene in leaves. Furthermore, in Arabidopsis thaliana (L.) Heynh. long day conditions accelerate flowering through the expression of this gene [40,41].

Different studies have shown that exogenous GAs and GA biosynthesis inhibitors have affected petiole elongation. From these results it is assumed that endogenous $\mathrm{GA}_{1}$ (or $\mathrm{GA}_{3}$ ) and $\mathrm{GA}_{4}$ may be involved in petiole elongation of $C$. persicum Mill. In our experiments, we evaluated the effects of $\mathrm{GA}_{3}$ treatments on seed germination parameters and morpho-agronomic features as well quantitatively comparing the germination parameters used for seed germination studies (Table 2 and 6). Our results showed that by increasing the $\mathrm{GA}_{3}$ concentration, the plants significantly developed, especially at the administration of $100 \mathrm{mg} / \mathrm{L} \mathrm{GA}_{3}$ in long-day exposed species and 50 and $100 \mathrm{mg} / \mathrm{L} \mathrm{GA}_{3}$ in short-day exposed species.

Under long-day condition, C. africanum exhibited a major elongation of the plant and petiole, as well as root length and shoot formation when $50 \mathrm{mg} / \mathrm{L} \mathrm{GA}_{3}$ was applied. Comparatively, under 
short-day condition, a larger number of leaves and shoot formations were observed with $100 \mathrm{mg} / \mathrm{L}$ $\mathrm{GA}_{3}$, whereas under $150 \mathrm{mg} / \mathrm{L} \mathrm{GA}_{3}$ larger leaf areas and tubers were observed.

In C. cyprium, under long-day condition, fewer numbers of roots, but an increased length were observed at the concentration of $50 \mathrm{mg} / \mathrm{L} \mathrm{GA}_{3}$, whereas an increased tuber diameter and shoot formations were observed at the concentration of $100 \mathrm{mg} / \mathrm{L} \mathrm{GA}_{3}$. Under short-day condition, at the concentration of $100 \mathrm{mg} / \mathrm{L} \mathrm{GA}_{3}$ the tuber diameter increased and at $150 \mathrm{mg} / \mathrm{L} \mathrm{GA} 3$ the leaf area increased, while the roots length decreased a better shoot formation was observed.

C. hederifolium exhibited a larger number of roots and an increased root length when $50 \mathrm{mg} / \mathrm{L} \mathrm{GA}_{3}$ was applied. The $100 \mathrm{mg} / \mathrm{L} \mathrm{GA}_{3}$ increased the petiole length and the shoot formation, under long-day exposure treatment. Comparatively, under short-day condition an increase in leaf area, tuber diameter and a decrease in root length but a better shoot formation were recorded when $100 \mathrm{mg} / \mathrm{L} \mathrm{GA}$ was applied. At the concentration of $150 \mathrm{mg} / \mathrm{L} \mathrm{GA}_{3}$ a larger number of leaves were noticed and a decrease in tuber diameter.

Under long-day exposure treatment, C. mirabile exhibited an increased number of leaves under control and at $100 \mathrm{mg} / \mathrm{LGA}_{3}$ an increase in petiole length and leaf area were recorded. Under short-day condition an increase in petiole, root length and tuber diameter were noticed when $50 \mathrm{mg} / \mathrm{L} \mathrm{GA}_{3}$ was applied.

In the case of $C$. pseudibericum the germination was irregular and none of the Cyclamen species germinated when $150 \mathrm{mg} / \mathrm{L} \mathrm{GA}_{3}$ was applied, under long-day exposure treatment. Compared to control, the concentration of $100 \mathrm{mg} / \mathrm{L} \mathrm{GA} 3$ exhibited an increased leaf area and tuber formation. Futhermore, increased root length and shoot formation were recorded. Under short-day condition, a larger number of leaves and an increase in tuber diameter were noticed at control. At the concentration of $100 \mathrm{mg} / \mathrm{L} \mathrm{GA}_{3}$ an increase in leaf area and root length were recorded.

Similar findings had been described by Oh and Kim [7], where the administration of $\mathrm{GA}_{3}$ at a concentration of $100 \mathrm{mg} / \mathrm{L}$ increased petiole elongation and plant height of Cyclamen persicum 'Metis Scarlet Red'. Alshakhaly and Qrunfleh [9] reported that foliar applications of $\mathrm{GA}_{3}$ with concentrations ranging from 25 to $100 \mathrm{mg} / \mathrm{L}$ on Cyclamen persicum specie effectively increased petiole elongation and flower development. Consequently, increased active GAs promoted petiole elongation and the positive effect of total contents of active GAs was greater under low rather than high irradiance [8]. This result might be caused by different $\mathrm{GA}_{3}$ concentrations and time of application. Positive effects have been obtained with regards to plant growth and development by $\mathrm{GA}_{3}$ applications in Antirrhinum majus L. cv. Rocket Pink (Rocket Pink snapdragon) and Polianthes tuberosa L. (tuberose) [42,43]. The latter had similar results to Cyclamen in petiole and leaf area with $\mathrm{GA}_{3}$ at $100 \mathrm{mg} / \mathrm{L}$. Alcalá-Rico et al. [44] reported that gibberellic acid increased the desirable characteristics of physiological potential of the germination of Capsicum annuum var. glabriusculum (Indian pepper) genotypes. Their results showed that dormancy of Capsicum seeds is generally influenced by physiological aspects. Furthermore, $\mathrm{GA}_{3}$ slightly promoted stem elongation in Matthiola incana (L.) R.Br (hoary stock) [11].

Fagge and Manga (2011) [45] studied the effect of $\mathrm{GA}_{3}$ application on the growth and seedling establishment of Bougainvillea glabra (paperflower), Ixora coccinea (jungle geranium) and Rosa chinensis (Chinese rose). Their results showed that the concentration of $100 \mathrm{mg} / \mathrm{L} \mathrm{GA} 3$ gave better results in terms of root establishment, growth and development in all studied species. Punetha et al., 2018 [46], studied the effect of $\mathrm{GA}_{3}$ application $(100 \mathrm{mg} / \mathrm{L}$ ) on Hydrangea (hortensia) cuttings with better results in terms of shoot number and length, number of leaves and survival percent and lower mortality under shade conditions, compared to open conditions.

Four concentrations of $\mathrm{GA}_{3},(0.05,0.5,5.0$, or $50 \mathrm{mg} / \mathrm{L})$ were applied to the root systems of seven Pelargonium (geranium) cultivars. With increased $\mathrm{GA}_{3}$ concentration the relative growth rate of all cultivars tested increased with GA3 treatments. In conjunction with the increase in growth rate, each of the cultivars showed a reduction in the root: shoot ratio [47].

As mentioned above, irradiance is also an important factor in the development of Cyclamen species which are mostly found at the base of Abies-Fagus forests. Ravnjak et al. [48] found that populations of 
Cyclamen species are capable of surviving in forest gaps due to increased anthocyanin and quercetin content, which protect plants against strong solar radiation. Furthermore, Osterc et al. [49] found that Cyclamen rosettes of long-day exposed plants were larger compared to those of short-day exposed. In Arabidopsis high-light exposure had a negative effect on plant development, compared to low-light exposure. [50].

In previous reports, Oh et al. [51,52] found that Cyclamen persium cv. 'Metis Scarlet Red' plants kept in short day conditions induced leaf expansion and petiole elongation, whereas those kept in long day conditions mainly expressed longer petioles. Similar results were found in petiole elongation at C. persicum at different developmental stages [7]. Furthermore, Cheon et al. [53] reported that most of the growth characteristics, including plant height, number of leaves and flowers, leaf area, tuber size and roots length were enhanced under long-day conditions. On the other hand, higher concentrations of GA $3(200 \mathrm{mg} / \mathrm{L}, 300 \mathrm{mg} / \mathrm{L}$ and $400 \mathrm{mg} / \mathrm{L})$ increased the vegetative growth of Chrysanthemum morifolium cv. Thai Chen Queen (florist's daisy) under short day conditions [54].

$\mathrm{GA}_{3}$ treatment was shown to be specie-specific and dose-dependent.

Due to the diversity of the genotypes and their great adaptability to different environments, these species are important phytogenetic resources for Cyclamen breeding programs [55]. Differences in genotypes' genetic diversity can present high phenotypic plasticity and variation of morphological traits [56]. Therefore, variations of the germination capacity among and within Cyclamen specie are an adaptation to the particular conditions of local populations and habitats [57]. Within the same context, Curuk et al. $[58,59]$ found that measurements related to morphological characteristics had great variation indicating differences between the studied species, confirmed also by the use of PCA which showed grouping of characters into species-specific clusters.

The data provided here reveal the response of long and short day exposed Cyclamen species under different $\mathrm{GA}_{3}$ concentrations, which furthers our knowledge of how these plants respond to high and low light intensity stress, as well as their germination capacity induced by $\mathrm{GA}_{3}$ application. The relationships between the used germination parameters are important aspects that will allow us to predict certain traits in future work. Furthermore, these findings suggest the need to deepen the research on the dose and methods of application of $\mathrm{GA}_{3}$, as well as the usage of multiple germination parameters in order to provide reliable germination data.

\section{Conclusions}

To our knowledge, this study presents the first report on the investigation of several germination parameters, seedling growth performance and photosynthetic capacity in five Cyclamen species. There were distinct morphological differences and germination parameters among all studied species which allowed them to be clearly distinguished based on germination traits. In the long-day exposure treatment, in terms of plant development the best $\mathrm{GA}_{3}$ concentration was $150 \mathrm{mg} / \mathrm{L}$ in C. cyprium and C. mirabile. In the short-day exposure treatment, increased plant elongation was observed in C. cyprium and C. mirabile, followed by C. pseudibericum at the concentration of 50 and $100 \mathrm{mg} / \mathrm{L}$, respectively. The use of wild genetic resources to expand the Cyclamen database and in vitro preservation remains a relatively unexplored subject in Cyclamen biology. As future opportunities for research, the expression of related genes in lowering the effect of light intensity stress should be evaluated.

Author Contributions: Conceptualization, M.C.-C., C.R.S. and R.M.; methodology, C.R.S. and R.M.; data collection and analysis, M.C.-C., manuscript design methodology, C.R.S. and R.M.; software, M.C.-C.; validation, C.R.S., D.P. and R.M.; writing-original draft preparation, M.C.-C., C.R.S. and R.M.; writing-review and editing, M.C.-C., C.R.S., R.M.; supervision, D.P.; funding acquisition, R.M. All authors have read and approved the final manuscript.

Funding: The publication was supported by funds from the National Research Development Projects to finance excellence (PFE)-37/2018-2020 granted by the Romanian Ministry of Research and Innovation.

Conflicts of Interest: The authors declare no conflict of interest. 


\section{References}

1. Grey-Wilson, C. Cyclamen (A Guide for Gardeners, Horticulturists and Botanists); B.T. Bastsford Publishers: London, UK, 2015; pp. 182-197. ISBN 9781849942218.

2. Schweizer, F.; Hasinger, O. Cyclamen purpurascens. The IUCN Red List of Threatened Species 2014: e.T196750A2475951. Available online: https://www.iucnredlist.org/species/196750/2475951 (accessed on 31 January 2020). [CrossRef]

3. Moser, D.M.; Gygax, A.; Bäumler, B.; Wyler, N.; Palese, R. Liste Rouges des Espèces Menacées de Suisse. Fougères et Plantes à Fleurs. Berne et Genève, Office fédéral de L'environnement, des Forêts et du Paysage (OFEFP); Centre du Réseau Suisse de Floristique (CRSF) et Conservatoire et Jardin Botaniques de Genève: Chambésy, Switzerland, 2002; p. 120.

4. Kathe, W.; Honnef, S.; Heym, A. Medicinal and Aromatic Plants in Albania, Bosnia-Herzegovina, Bulgaria, Croatia and Romania; Bundesamt für Naturschutz BfN Skripten: Bonn, Germany, 2003; p. 91.

5. Lee, J.W.; Kim, Y.C.; Kim, J.U.; Jo, I.H.; Kim, K.H.; Kim, D.H. Effects of gibberellic acid and alternating temperature on breaking seed dormancy of Panax ginseng CA Meyer. Korean J. Med. Crop Sci. 2016, 4, $284-293$. [CrossRef]

6. Urbanova, T.; Leubner-Metzger, G. Gibberellins and seed germination. Annu. Plant Rev. 2018, 49, $253-284$.

7. Oh, W.; Kim, K.S. Light intensity and temperature regulate petiole elongation by controlling the content of and sensitivity to gibberellin in Cyclamen persicum. Hortic. Environ. Biotechnol. 2014, 55, 175-182. [CrossRef]

8. Oh, W.; Kim, J.; Kim, Y.H.; Lee, I.J.; Kim, K.S. Shoot elongation and gibberellin contents in Cyclamen persicum are influenced by temperature and light intensity. Hortic. Environ. Biotechnol. 2015, 56, 762-768. [CrossRef]

9. Alshakhaly, Z.M.; Qrunfleh, M.M. Effect of plant growth regulators on flower development and quality of five Cyclamen persicum hybrids. In Proceedings of the XXX International Horticultural Congress IHC2018: International Symposium on Ornamental Horticulture and XI International, Istanbul, Turkey, 12-16 August 2018; Volume 1263, pp. 215-222.

10. Dong, B.; Deng, Y.; Wang, H.; Gao, R.; Stephen, G.U.; Chen, S.; Chen, F. Gibberellic acid signaling is required to induce flowering of chrysanthemums grown under both short and long days. Int. J. Mol. Sci. 2017, 18, 1259. [CrossRef]

11. Hisamatsu, T.; Koshioka, M.; Kubota, S.; Fujime, Y.; King, R.W.; Mander, L.N. The role of gibberellin biosynthesis in the control of growth and flowering in Matthiola incana. Physiol. Plant. 2000, 109, 97-105. [CrossRef]

12. Mutasa-Göttgens, E.; Hedden, P. Gibberellin as a factor in floral regulatory networks. J. Exp. Bot. 2009, 60, 1979-1989. [CrossRef]

13. Wilkie, J.D.; Sedgley, M.; Olesen, T. Regulation of floral initiation in horticultural trees. J. Exp. Bot. 2008, 59, 3215-3228. [CrossRef]

14. Wilson, R.N.; Heckman, J.W.; Somerville, C.R. Gibberellin is required for flowering in Arabidopsis thaliana under short days. Plant Physiol. 1992, 100, 403-408. [CrossRef]

15. Wahyuni, S.; Krisantini, S.; Johnston, M.E. Plant growth regulators and flowering of Brunonia and Calandrinia sp. Sci. Hortic. 2011, 128, 141-145. [CrossRef]

16. Sumanasiri, H.; Krishnarajah, S.A.; Eeswara, J.P. Effect of gibberellic acid on growth and flowering of Henckelia humboldtianus Gardner (Ceylon Rock Primrose). Sci. Hortic. 2013, 159, 29-32. [CrossRef]

17. Al-Khassawneh, N.M.; Karam, N.S.; Shibli, R.A. Growth and flowering of black iris (Iris nigricans Dinsm.) following treatment with plant growth regulators. Sci. Hortic. 2006, 107, 187-193. [CrossRef]

18. Bergmann, B.A.; Dole, J.M.; McCall, I. Gibberellic acid shows promise for promoting flower stem length in four field-grown cut flowers. HortTechnology 2016, 26, 287-292. [CrossRef]

19. Toscano, S.; Trivellini, A.; Ferrante, A.; Romano, D. Physiological mechanisms for delaying the leaf yellowing of potted geranium plants. Sci. Hortic.-Amst. 2018, 242, 146-154. [CrossRef]

20. Skene, K.G.M.; Lang, A. Native Gibberellins+ Flower Formation in Bryophyllum daigremontianum. Plant Physiol. 1964, 39, 37.

21. Zeevaart, J.A.D. Changes in the gibberellin content of Bryophyllum daigremontianum in connection with floral induction. Neth. J. Agric. Sci. 1969, 17, 215-220.

22. Huang, C.H. Studies on Flowering Physiology, Interspecies Hybridization and ISSR Analysis of Kalanchoe Species Native in Taiwan. Ph.D. Thesis, National Chung Hsing University, Taichung, Taiwan, 2007. 
23. The Cyclamen Society. Available online: https://www.cyclamen.org (accessed on 16 August 2019).

24. Al-Ansari, F.; Ksiksi, T. A Quantitative Assessment of Germination Parameters: The Case of Crotalaria Persica and Tephrosia apollinea. Open Ecol. J. 2016, 9, 13-21. [CrossRef]

25. Kader, M.A. A comparison of seed germination calculation formulae and the associated interpretation of resulting data. J. Proc. R. Soc. N. S. W. 2005, 138, 65-75.

26. Ellis, R.H.; Roberts, E.H. Towards a rational basis for testing seed quality. In Seed Production; Hebblethwaite, P.D., Ed.; Butterworths: London, UK, 1980; pp. 605-635.

27. Abdul-Baki, A.A.; Anderson, J.D. Relationship between Decarboxylation of Glutamic Acid and Vigor in Soybean Seed 1. Crop Sci. 1973, 13, 227-232. [CrossRef]

28. Al-Mudaris, M.A. Notes on various parameters recording the speed of seed germination. Der Tropenlandwirt-J. Agric. Trop. Subtrop. 1998, 99, 147-154.

29. Ranal, M.A.; Santana, D.G.D. How and why to measure the germination process? Braz. J. Bot. 2006, $29,1-11$. [CrossRef]

30. Janmohammadi, M.; Sabaghnia, N. Effect of pre-sowing seed treatments with silicon nanoparticles on germinability of sunflower (Helianthus annuus). Bot. Lith. 2015, 21, 13-21. [CrossRef]

31. Yasmeen, A.; Basra, S.M.A.; Wahid, A.; Nouman, W.; Rehman, H.U. Exploring the potential of Moringa oleifera leaf extract (MLE) as a seed priming agent in improving wheat performance. Turk. J. Bot. 2013, 37, 512-520.

32. Kumar, S.; Malik, T.P.; Mor, V.S.; Kumar, P. Effect of gibberellic acid on seed quality of coriander (Coriandrum sativum L.). J. Pharmacogn. Phytochem. 2018, 7, 830-832.

33. Zulfiqar, F.; Younis, A.; Abideen, Z.; Francini, A.; Ferrante, A. Bioregulators Can Improve Biomass Production, Photosynthetic Efficiency, and Ornamental Quality of Gazania rigens L. Agronomy 2019, 9, 773. [CrossRef]

34. Hanyan, X.; Du Hongmei, H.D. Effects of GA_3 on the Seed Germination of Cyclamen Persicum. Seed 2006, 4, 62.

35. Sgamma, T. Juvenility, 2nd ed.; Thomas, B., Murphy, D.J., Murray, B.G., Eds.; Encyclopedia of Applied Plant Sciences; Academic Press: Cambridge, MA, USA, 2017; Volume 1, pp. 437-441.

36. Barratt, N.M.; Davies, P.J. Developmental changes in the gibberellin-induced growth response in stem segments of light-grown pea genotypes. Plant Growth Regul. 1997, 21, 127-134. [CrossRef]

37. Sansberro, P.A.; Mroginski, L.A.; Masciarelli, O.A.; Bottini, R. Shoot growth in Ilex paraguariensis plants grown under varying photosynthetically active radiation is affected through gibberellin levels. Plant Growth Regul. 2002, 38, 231-236. [CrossRef]

38. Metzger, J.D. Gibberellin and light regulated petiole growth in Thlaspi arvense L. Plant Physiol. 1988, 86, 237-240. [CrossRef]

39. Pinthus, M.J.; Abraham, M. Effects of light, temperature, gibberellin (GA3) and their interaction on coleoptile and leaf elongation of tall, semi-dwarf and dwarf wheat. Plant Growth Regul. 1996, 18, 239-247. [CrossRef]

40. Song, Y.H.; Ito, S.; Imaizumi, T. Flowering time regulation: Photoperiod-and temperature-sensing in leaves. Trends Plant Sci. 2013, 18, 575-583. [CrossRef] [PubMed]

41. Shim, J.S.; Imaizumi, T. Circadian clock and photoperiodic response in Arabidopsis: From seasonal flowering to redox homeostasis. Biochemistry 2014, 54, 157-170. [CrossRef] [PubMed]

42. Asil, M.H.; Roein, Z.; Abbasi, J. Response of tuberose (Polianthes tuberose L.) to gibberellic acid and benzyladenine. Hortic. Environ. Biotechnol. 2011, 52, 46. [CrossRef]

43. Malik, S.A.; Neelofar, Z.A.; Nazki, I.T.; Mir, S.A.; Khan, F.A.; Pukhta, M.S. Effect of Gibberellic acid, spacing and nutrient sprays on growth and flowering in snapdragon (Antirrhinum majus L.) cv. Rocket Pink. Int. J. Plant Soil Sci. 2011, 28, 1-6. [CrossRef]

44. Alcalá-Rico, J.S.G.J.; López-Benítez, A.; Vázquez-Badillo, M.E.; Sánchez-Aspeytia, D.; Rodríguez-Herrera, S.A.; Pérez-Rodríguez, M.Á.; Ramírez-Godina, F. Seed Physiological Potential of Capsicum annuum var. glabriusculum Genotypes and Their Answers to Pre-Germination Treatments. Agronomy 2019, 9, 325. [CrossRef]

45. Fagge, A.A.; Manga, A.A. Effect of Sowing Media and Gibberellic Acid on the Growth and Seedling Establishment of Bougainvillea glabra, Ixora coccinea and Rosa chinensis. 2. Root Characters. Bayero J. Pure Appl. Sci. 2011, 4, 155-159. [CrossRef]

46. Punetha, P.; Rawat, T.; Bohra, M.; Trivedi, H. Effects of various concentrations of GA3 and NAA on cuttings of hydrangea under shade net conditions. J. Hill Agric. 2018, 9, 260-264. [CrossRef] 
47. Arteca, R.N.; Schlagnhaufer, C.D.; Arteca, J.M. Root applications of gibberellic acid enhance growth of seven Pelargonium cultivars. HortScience 1991, 26, 555-556. [CrossRef]

48. Ravnjak, B.; Bavcon, J.; Osterc, G. Physiological response of local populations of species Cyclamen purpurascens Mill. to forest gaps. Appl. Ecol. Environ. Res. 2019, 17, 11489-11508. [CrossRef]

49. Osterc, G.; Petkovsek, M.M.; Stampar, F.; Ravnjak, B.; Bavcon, J. Impact of specific environmental characteristics of the site of origin (shady, sunny) on anthocyanin and flavonol contents of replanted plants at common cyclamen (Cyclamen purpurascens Mill.). Acta Physiol. Plant 2017, 39, 64. [CrossRef]

50. Huang, J.; Zhao, X.; Chory, J. The Arabidopsis Transcriptome Responds Specifically and Dynamically to High Light Stress. Cell Rep. 2019, 29, 4186-4199. [CrossRef] [PubMed]

51. Oh, W.; Kim, K.S. Temperature and light intensity induce morphological and anatomical changes of leaf petiole and lamina in Cyclamen persicum. Hortic. Environ. Biotechnol. 2010, 51, 494-500.

52. Oh, W.; Kim, K.S. Developmental stage and temperature influence elongation response of petiole to low irradiance in Cyclamen persicum. Korean J. Hortic. Sci. 2010, 28, 719-727.

53. Cheon, I.H.; Oh, W.; Park, J.H.; Kim, K.S. Long day and high photosynthetic photon flux promote the growth and flowering of Cyclamen persicum. Hortic. Environ. Biotechnol. 2006, 47, 353-358.

54. Aparna, V.; Prakash, K.; Neema, M.; Ajay, A.; Kumar, N.; Singh, M.C. Effect of Gibberellic Acid on plant growth and flowering of Chrysanthemum cv. Thai Chen Queen under short day planting conditions. Int. J. Agric. Sci. 2018, 10, 6274-6278.

55. Simsek, O.; Curuk, P.; Aslan, F.; Bayramoglu, M.; Izgu, T.; da Silva, J.A.T.; Mendi, Y.Y. Molecular characterization of Cyclamen species collected from different parts of Turkey by RAPD and SRAP markers. Biochem. Genet. 2017, 55, 87-102. [CrossRef]

56. Thompson, J.D.; Gauthier, P.; Papuga, G.; Pons, V.; Debussche, M.; Farris, E. The conservation significance of natural hybridisation in Mediterranean plants: From a case study on Cyclamen (Primulaceae) to a general perspective. Plant Biol. 2018, 20, 128-138. [CrossRef]

57. Yesson, C.; Culham, A.A. Phyloclimatic study of Cyclamen. BMC Evol. Biol. 2006, 6, 72. [CrossRef]

58. Curuk, P.; Sogut, Z.; Bozdogan, E.; Izgu, T.; Sevindik, B.; Tagipur, E.M.; Mendi, Y.Y. Morphological characterization of Cyclamen sp. grown naturally in Turkey: Part I. S. Afr. J. Bot. 2015, 100, 7-15. [CrossRef]

59. Curuk, P.; Sogut, Z.; Izgu, T.; Sevindik, B.; Tagipur, E.M.; da Silva, J.A.T.; Mendi, N.Y. Morphological characterization of Cyclamen sp. grown naturally in Turkey: Part II. Acta Sci. Pol. Hortorum Cultus 2016, 15, 205-224. [CrossRef] 